\title{
Az Osteoporosis Health Belief Scale kérdőív magyar nyelvü validálása
}

\author{
Tardi Péter - Kovács Ildikó - Makai Alexandra dr. - Szilágyi Brigitta \\ Hock Márta dr. - Járomi Melinda dr.
}

Pécsi Tudományegyetem, Egészségtudományi Kar, Fizioterápiás és Sporttudományi Intézet, Pécs

Bevezetés: A nemzetközi szakirodalomban számos betegséget illetően elérhető betegségspecifikus tudást és attitűdöt mérő kérdőív. Magyarországon az osteoporosis témakörében validált kérdőívek tárháza meglehetősen hiányos. Célkitüzés: Célunk volt a csontritkulás-specifikus magatartás és attitüd vizsgálatára alkalmas Osteoporosis Health Belief Scale (OHBS-) kérdőív magyar nyelvre történő validációja, melynek segítségével mérhetővé válna a magyar anyanyelvú nők csontritkulással kapcsolatos attitúdje.

Módszer: A kérdő́iv magyar nyelvre validálása a 2000-ben megfogalmazott hatlépcsős irányelv szerint történt. A külső validitás vizsgálatához az Osteoporosis Knowledge Assessment Tool (OKAT-) kérdő́ivet használtuk. Mintánkat 600 fő alkotta; statisztikai számításaink során leíró statisztikát készítettünk, különbözőségi vizsgálatokat végeztünk, a belső konzisztencia vizsgálatára Cronbach-alfa-értéket számítottunk, a konvergens validitás és a teszt-reteszt mérések vizsgálatához Spearman-féle korrelációs koefficienst számítottunk. A kérdő́iv belső struktúrájának vizsgálatához faktorelemzést végeztünk. Ennek megfelelően Kaiser-Meyer-Olkin (KMO)-tesztet és Bartlett-próbát számítottunk. Eredmények: Mintánk (37,7 \pm 13,15 életév) az OHBS $(126,28 \pm 14,85$ pont $)$ és az OKAT $(8,78 \pm 3,1)$ tekintetében egyaránt alacsony pontszámot ért el. A teljes kérdőívre kivetített Cronbach-alfa-érték 0,802 volt. A faktorelemzés $(\mathrm{KMO}=0,886$; Bartlett-próba p<0,001) 7 faktort különített el, melyek megfeleltethetők az eredeti faktoroknak. A teszt-reteszt során a Spearman-féle korrelációs koefficiens 0,921 és 1,000 közötti értéket mutatott. Az OKAT- és az OHBS-dimenziók összevetésekor számos szignifikáns kapcsolatot találtunk.

Megbeszélés: A vizsgálati eredmények megfelelnek az eredeti kérdőív szerinti, továbbá a más nyelvre történt validálás során kapott eredményeknek.

Következtetés: Eredményeink alapján a magyar nyelvű OHBS csontritkulás-specifikus attitűdöt és magatartást vizsgáló kérdőívet megbízható és valid kérdőívnek tartjuk.

Orv Hetil. 2021; 162(37): 1494-1501.

Kulcsszavak: osteoporosis, egészségügyi ismeretek, egészségügyi tudás, validáció

\section{The Hungarian adaptation and validation of the Osteoporosis Health Belief Scale}

Introduction: In the international literature, several disease-specific questionnaires are available for many diseases. The opportunities of validated questionnaires are incomplete about osteoporosis in Hungarian language.

Objective: The aim of the study was to validate the Osteoporosis Health Belief Scale (OHBS) into Hungarian that would make it possible to measure the osteoporosis-related attitude for Hungarian-speaking women.

Method: The questionnaire was validated into Hungarian according to the six-step guideline outlined in 2000. The Osteoporosis Knowledge Assessment Tool (OKAT) questionnaire was used to examine external validity. Our sample consisted of 600 women. We performed descriptive statistics; Cronbach's alpha value was calculated for internal consistency, we calculated Spearman's correlation coefficient to examine external validity. We carried out factor analysis (Kaiser-Meyer-Olkin [KMO] test, Bartlett test) to examine whether the new questionnaire is suitable for measurements in the given language the same way as the original questionnaire.

Results: Our sample $(37.7 \pm 13.15$ years of age) achieved low score for both OHBS $(126.28 \pm 14.85)$ and OKAT $(8.78 \pm 3.1)$. The Cronbach's alpha value was 0.802 . Factor analysis $(\mathrm{KMO}=0.886$; Bartlett test $\mathrm{p}<0.001)$ identified 7 factors that can be similar to the original factors. During the test-retest, the Spearman correlation coefficient showed a value between 0.921 and 1.000 . When comparing the OKAT and OHBS dimensions we found several significant relationships.

Discussion: The results of the study are similar to the results of the original questionnaire validation as well as to other OHBS validation studies. 
Conclusion: Based on the results, we consider that the Hungarian form of the OHBS is a reliable and valid questionnaire.

Keywords: osteoporosis, health belief, health knowledge, validation study

Tardi P, Kovács I, Makai A, Szilágyi B, Hock M, Járomi M. [The Hungarian adaptation and validation of the Osteoporosis Health Belief Scale]. Orv Hetil. 2021; 162(37): 1494-1501.

(Beérkezett: 2021. január 31.; elfogadva: 2021. február 21.)

\begin{abstract}
Rövidítések
ELEF = Európai Lakossági Egészségfelmérés; FRAX = (Fracture Risk Assessment Tool) a csonttörési rizikó felmérésére és az újabb csonttörés valószínűségének megállapítására alkalmas index $; \mathrm{IOF}=($ International Osteoporosis Foundation $) \mathrm{Nem}^{-}$ zetközi Osteoporosis Alapítvány; $\mathrm{KMO}=$ Kaiser-MeyerOlkin-teszt; OHBS = (Osteoporosis Health Belief Scale) a csontritkulás-specifikus magatartás és attitûd vizsgálatára alkalmas kérdö́v; OKAT = (Osteoporosis Knowledge Assessment Tool) a csontritkulás-specifikus tudásszintet értékelő index; PTE-KK = Pécsi Tudományegyetem, Klinikai Központ; Qualeffo-4l = (Quality of Life Questionnaire of the European Foundation for Osteoporosis) az Európai Osteoporosis Alapítvány életminőséget vizsgáló kérdőíve
\end{abstract}

A csontritkulás a csont struktúráját érintő megbetegedés, amely alacsony ásványianyag-sưrúséggel jár, továbbá a csontszövet mikroarchitektúrájának károsodásához vezet [1]. Népegészségügyi problémává nőtte ki magát, mivel számos vizsgálatban igazolták az osteoporosis negatív hatását a csontritkulásban szenvedők életminőségére, fizikális és funkcionális állapotára [2, 3]. 2020-ban az Európai Unió 5 legnagyobb országában (Egyesült Királyság - akkor még az Unió tagállama -, Franciaország, Németország, Olaszország, Spanyolország) és Svédországban végzett felmérés szerint a 60 -as éveikben járó nók 10\%-át, 70 és 80 éves kor között a nói nem 20\%-át, a nyolcadik évtizedben járó nôk 40\%-át, míg a 90 év feletti női lakosság 66\%-át érintette az osteoporosis [4]. Világviszonylatban 8,9 millió, az Európai Unió országaiban 3,5 millió csonttörést regisztrálnak éves szinten az osteoporosis talaján [5]. 2020. évi adatok alapján Európában napi szinten 7332 törés hátterében áll a csontritkulás [4]. A csontritkulásban szenvedó betegek és a betegségbő́l adódó szövődmények utókezelésének költsége jelentôs terhet ró az egészségügyi ellátórendszerre, az Európai Unió országaiban megközelítőleg 37 milliárd eurót jelent [5].

A csontritkulás Magyarországon is népbetegségnek számít, a 2019-ben végzett Európai Lakossági Egészségfelmérés (ELEF 2019) alapján a magyar lakosság 5,6\%-át érinti diagnosztizáltan az osteoporosis [6]. Az International Osteoporosis Foundation (IOF) adatai is ezt támasztják alá, miszerint 550000 nyilvántartott, csontritkulásban szenvedő beteg él Magyarországon, akik körében éves szinten 102000 csonttörést regisztrálnak. Az IOF adatai alapján 2025-re a csontritkulás kezelési költsége hazánkban várhatóan eléri a 226 millió eurót [7]. A becslések szerint azonban az osteoporosisban szenvedôk valós száma a regisztrált betegek számánál jóval magasabb, megközelítheti az l millió (600 000 nói és 300000 férfi) föt, figyelembe véve a szűrôvizsgálatokon való alacsony részvételt.

A nemzetközi szakirodalom alapján a csontritkulás megelőzésében, valamint annak hatékony, sikeres kezelésében a betegségspecifikus tudásszint fontos szerepet tölt be. Az osteoporosisspecifikus tudás szerepe megkérdőjelezhetetlen a megfelelő, betegségspecifikus attitűd és magatartás kialakításában, az adherencia létrejöttében [8]. Az adherencia túlmutat a compliance definícióján, a beteg-együttmúködést és a terápiahüséget írja le, ugyanakkor az orvos és a beteg közötti egyenrangú viszonyt feltételez. Az adherencia az egészségügyi szakemberrel egyeztetett ajánlásoknak megfelelő egyéni magatartás a gyógyszerszedés, a diéta és az életmódváltás területén [9].

Napjainkban a betegedukáció jelentősége és relevanciája számos kórképet, így az osteoporosist illetően is körvonalazódni látszik [10]. A betegségspecifikus tudás és attitúd fejlesztéséhez, valamint betegedukációs programok kialakításához és azok monitorozásához nélkülözhetetlen egy magyar nyelvre validált kérdőív kialakítása.

Az osteoporosis témakörében magyar nyelvre validált vizsgálati eszközök és kérdőívek tárháza meglehetősen hiányos. A szakemberek számára elérhető a Fracture Risk Assessment Tool (FRAX), amely a csonttörési rizikó felmérésére és az újabb csonttörés valószínúségének megállapítására alkalmas index, továbbá a Quality of Life Questionnaire of the European Foundation for Osteoporosis (Qualeffo-41), amely a csontritkulás-specifikus életminőség vizsgálatára alkalmas $[11,12]$. Elérhető továbbá a 2020-ban általunk validált Osteoporosis Knowledge Assessment Tool (OKAT), amely a 24-44 éves magyar női populáció csontritkulás-specifikus tudásszintjét méri fel [13].

Az Osteoporosis Health Belief Scale (OHBS) a 18 év feletti női lakosság csontritkulás-specifikus attitúdjének és magatartásának vizsgálatára alkalmas. Jelenleg nem áll rendelkezésünkre magyar nyelvre validált, adherenciát és csontritkulás-specifikus magatartást vizsgáló kérdőív. 
Fontos lenne egy magyar nyelven elérhető kérdőív, melynek segítségével a csontritkulás-betegedukációs programok hatékonysága vizsgálhatóvá válna [14].

Vizsgálatunk célja volt az OHBS-kérdőív magyar nyelvű változatának validálása, megbízhatóságának és alkalmazhatóságának vizsgálata a magyar anyanyelvű nők körében.

\section{Módszer}

\section{Az OHBS-kérdöí jellemzöi}

Az OHBS-kérdőívet 1991-ben Kim és mtsai dolgozták ki [14]. Ugyan a kérdóívet számos alkalommal alkalmazták férfiak és nők együttes vizsgálatára és összehasonlítására, de eredendően a 18 év feletti női populáció csontritkulás-specifikus attitűdjének és magatartásának vizsgálatára validálták 201 résztvevő bevonásával [15]. Az OHBS 7 dimenziót foglal magában: „Hajlam a kórkép kialakulására”, „A kórkép súlyossága”, „A testmozgás előnyei”, „A kalciumbevitel előnyei”, „A testmozgás korlátai”, „A kalciumbevitel korlátai” és „Egészségügyi motiváció”. A 7 dimenzió összesen 42 kérdést/állítást tartalmaz, melyekre a válaszadó 1-tôl 5-ig terjedő Likert-skálán - ahol az 1: „Egyáltalán nem ért egyet”, az 5 : "Teljesen egyetért” - jelölheti meg a rá leginkább jellemző választ. Az egyes dimenziók pontszámának lehetséges tartománya 6 és 30 között van, így a teljes kérdőív pontszáma 42 és 210 között lehet. A dimenziók többségénél a magasabb pontszám jelzi a megfelelő prevenciós magatartást, míg a két korlátokról/akadályokról szóló dimenzióban az alacsonyabb pontszámok mutatják a megfelelő attitűdöt és meggyőződést. A 42 elemet tartalmazó kérdőív nem kategorizál megfelelő vagy nem megfelelő, jó vagy rossz attitűdre, alkalmazásának fó indikációs területe a betegedukációs programok hatékonyságának vizsgálata [15].

\section{A validálás folyamata}

Az OHBS-kérdőív magyar nyelvre fordítása és validálása a 2000-ben megfogalmazott hatlépcsős irányelv szerint történt: fordítás, szintézis kialakítása, visszafordítás, előtesztelés, pszichometriai tulajdonságok vizsgálata (az adaptált mérőeszköz érvényességének és megbízhatóságának elemzése arra vonatkozóan, hogy a kérdőív következetesen mér-e, valamint azt a tudást méri-e, amelyet témája megcéloz) [16]. Első lépésként az angol nyelvü eredeti kérdőív szerzőjének engedélyét és támogatását kértük, majd a kérdőívet magyarra fordítottuk. A fordítást két független személy végezte: egy egészségügyi végzettséggel nem rendelkező szakfordító, illetve egy felsőfokú angol nyelvvizsgával rendelkező egészségügyi szakdolgozó. A két magyar fordításból kialakításra került egy szintézis, melyet egy 30 fóból álló, a 18. életévet már betöltött, magyar anyanyelvű női mintán előteszteltünk. Az előtesztelés során jelzett, problémát okozó/értelme- zést zavaró kifejezéseket javítottuk. Ennek megfelelően az „osteoporosis” kifejezést „csontritkulás”-ra, az „optimális kalciumfogyasztást” „megfelelő kalciumbevitel”-re cseréltük. Az előtesztelés során kialakult végleges, magyar nyelvű kérdőív segítségével elvégeztük a belső konzisztencia vizsgálatát 40, magyar anyanyelvü, 18 év feletti nő részvételével. A konvergens validitás vizsgálatára nemzetközi minta alapján az OKAT-kérdőívet használtuk, mely kérdőív az osteoporosisspecifikus tudást vizsgálja 24-44 éves nők körében [13, 17]. A két kérdőív alkalmas az osteoporosisspecifikus preventív tudás (OKAT) és attitűd (OHBS) vizsgálatára. Keresztmetszeti vizsgálatok eltérô eredményt mutatnak a betegségspecifikus tudásszint és a betegségspecifikus attitűd összefüggéseiről [18-20], ezért az eredeti kérdőív szerzőinek javaslatára egy saját szerkesztésú kérdőívet is kialakítottunk, melyben a szociodemográfiai adatok (életkor, a lakhely típusa, iskolai végzettség, foglalkozás) mellett a csontritkulás családi előfordulására és a résztvevők életmódbeli tényezőire (dohányzás, alkoholfogyasztás) kérdeztünk rá.

A kérdőív kitöltése előtt a résztvevők részletes tájékoztatást kaptak szóban és írásban, majd a beleegyező nyilatkozat aláírását követően töltötték ki a kérdő́ivet.

A vizsgálatot a PTE-KK Regionális Kutatásetikai Bizottsága engedélyezte, és 8109 - PTE 2019 ügyiratszámon nyilvántartásba vette.

\section{A résztvevook kiválasztása és a minta jellemzői}

Keresztmetszeti vizsgálatunkhoz a résztvevőket nem véletlenszerü kiválasztással toboroztuk a Pécsi Tudományegyetemnek, a Baranya megyei fitnesztermeknek és sportközösségeknek, valamint a Vasútegészségügyi Nonprofit Közhasznú Kft. Harkányi Mozgásszervi Rehabilitációs Intézetének segítségével, továbbá különböző közösségi oldalak felületén. Beválasztásra kerültek, akik megfeleltek a beválasztási kritériumoknak, és vállalták a kutatásban való részvételt. A beválasztási kritériumok között szerepelt a 18. életév betöltése, a női nem, feltétel volt a magyar anyanyelvúség, az önkéntesség (a résztvevők részletes tájékoztatást követően szóban és írásban adták beleegyezésüket). A kizárási kritériumok között szerepeltek azon egészségi problémák, amelyek az egyént mozgásában nagymértékben korlátozzák, a mentális problémák, továbbá kizárásra került minden olyan résztvevő, aki speciális diétát folytat. A mintát így 600 fő alkotta. Az elemszám meghatározása során figyelembe vettük a 10 résztvevő/1 item (kérdés) szabályt a feltáró faktorelemzéshez [21].

\section{Statisztikai módszertan}

A statisztikai számításokat az SPSS 24.0 verziójú szoftverrel (IBM Corporation, Armonk, NY, Amerikai Egyesült Államok) végeztük, mellyel leíró statisztikát készítet- 
tünk, különbözőségi vizsgálatokat végeztünk. Eredményeinket $\mathrm{p}<0,05$ esetén tekintettük szignifikánsnak.

A kérdőív belső struktúrájának vizsgálatára feltáró faktorelemzést (főkomponens-analízist) végeztünk. A módszerrel a nagyszámú változó olyan faktorváltozókba vonható össze, amelyek közvetlenül nem figyelhetők meg. Ennek megfelelően Kaiser-Meyer-Olkin (KMO)-tesztet és Bartlett-próbát alkalmaztunk. Amennyiben a $\mathrm{KMO}>0,6$, valamint a Bartlett-próba szignifikanciaértéke $\mathrm{p}<0,05$, az adatok alkalmasak a feltáró faktoranalízisre. A feltáró faktorelemzés a teszt kérdéseiből alskálákat képez a faktorok létrehozásával, melyek az azonos témájú kérdéseket tartalmazzák. A létrejött új faktorok kumulatív varianciája legalább a teljes variancia $60 \%$-át kell, hogy magyarázzák [22].

Az új adaptált mérôeszköz megbízhatóságának vizsgálata során a kérdőív belső konzisztenciájának meghatározására Cronbach-alfa-értéket számítottunk. A vizsgálat a kérdőív megbízhatóságát méri, azt mutatja meg, hogy a mérőeszköz vagy alskálák egyes tételei milyen mértékben mérik ugyanazt, értéke 0 és 1 közötti; vizsgálatunkban 0,7 felett tekintettük megbízhatónak a tesztet vagy annak egy-egy alskáláját [23].

A kérdőív megbízhatóságát teszt-reteszt mérési eredmények vizsgálatával is megerősítettük, melynek során Spearman-féle korrelációs koefficienst számítottunk.

A külső konvergens validitás vizsgálatához az OKATkérdőívet alkalmaztuk. A vizsgálat során korrelációs kapcsolatot kerestünk a két kérdőív eredménye, a betegségspecifikus tudás és a betegségspecifikus attitűd között Spearman-féle rangkorrelációs elemzéssel.

\section{Eredmények}

Mintánkat 600 résztvevő alkotta, akiknek átlagéletkora $37,7 \pm 13,15$ év volt; a legfiatalabb 24, a legidősebb 75 éves volt. Megközelítőleg fele-fele arányban volt jelen a vizsgálatban a 40 év alatti $(\mathrm{n}=323)$ és a 40 év feletti ( $\mathrm{n}=277$ ) női populáció.

A résztvevők lakhelyének típusát, családi állapotát, iskolai végzettségét tekintve rendkívül széles körü megoszlás figyelhető meg (1. táblázat).

A minta jellemzői közül kiemelendő, hogy a résztvevők jellemzően a fővárosban, megyeszékhelyen vagy városban laknak, elvétve kisebb településen. Legmagasabb iskolai végzettségüket figyelembe véve a középszintü iskolai végzettség, továbbá a nem egészségügyi főiskolai végzettség a leggyakoribb. Jellemzően nem dohányzó, alkalomszerűen alkoholt fogyasztó nők alkották a mintát. A résztvevők nagy arányban nem tudtak arról, hogy érintettek-e a csontritkulásban (41,3\%), vagy korábban családjukban előfordult volna $(26,7 \%)$ a kórkép.

Az OHBS tekintetében a megszerezhető 210 pontból mintánk átlagosan $126,28 \pm 14,85$ pontot szerzett. A kategóriák közül „A kórkép súlyossága” (16,16 + 5,66 pont) és a „Hajlam a kórkép kialakulására” (15,47 \pm 5,94 pont) dimenziók pontszáma szembetűnően

1. táblázat |A minta szociodemográfiai jellemzői

\begin{tabular}{|c|c|c|}
\hline & $\begin{array}{l}\text { A résztvevők } \\
\text { száma }\end{array}$ & $\begin{array}{c}\text { A } \\
\text { résztvevók } \\
\text { aránya }\end{array}$ \\
\hline \multicolumn{3}{|l|}{ Lakhely } \\
\hline Fôváros & 230 & $38,3 \%$ \\
\hline Megyeszékhely & 97 & $16,2 \%$ \\
\hline Város & 182 & $30,3 \%$ \\
\hline Falu & 57 & $9,5 \%$ \\
\hline Község, tanya & 34 & $5,7 \%$ \\
\hline \multicolumn{3}{|l|}{ Családi állapot } \\
\hline Egyedülálló/Elvált/Özvegy & 173 & $28,8 \%$ \\
\hline Házas & 238 & $39,7 \%$ \\
\hline Párkapcsolatban él & 189 & $31,5 \%$ \\
\hline \multicolumn{3}{|l|}{ A legmagasabb iskolai végzettség } \\
\hline Alapszint & 11 & $1,8 \%$ \\
\hline Középszint & 288 & $48 \%$ \\
\hline $\begin{array}{l}\text { Főiskolai szint (Bsc) - } \\
\text { Nem egészségügyi }\end{array}$ & 161 & $26,8 \%$ \\
\hline Főiskolai szint (Bsc) - Egészségügyi & 28 & $4,7 \%$ \\
\hline $\begin{array}{l}\text { Egyetemi szint (Msc) - } \\
\text { Nem egészségügyi }\end{array}$ & 95 & $15,8 \%$ \\
\hline Egyetemi szint (Msc) - Egészségügyi & 11 & $1,8 \%$ \\
\hline Tudományos fokozat (PhD) & 6 & $1 \%$ \\
\hline
\end{tabular}

\section{Foglalkozás}

Egészségügyi szakma

$91 \quad 15,2 \%$

Nem egészségügyi szakma

$509 \quad 84,8 \%$

Dohányzás

Nem dohányzik

Havonta egyszer dohányzik

Hetente egyszer dohányzik

Naponta dohányzik

Naponta 1-10 szálat szív el

Naponta egy doboz cigarettát szív el

464

24

20

4

38

29

Alkoholfogyasztás

Nem fogyaszt alkoholt

Évente fogyaszt alkoholt

169

139

Havonta fogyaszt alkoholt

187

101

Hetente fogyaszt alkoholt

\section{4}

Érintett-e Ön a csontritkulásban?

$\begin{array}{lrr}\text { Érintett } & 61 & 10,2 \% \\ \text { Nem érintett } & 351 & 58,5 \% \\ \text { Nem tudom } & 188 & 41,3 \%\end{array}$

Előfordult a családjában csontritkulás?

\section{Előfordult}

248

Nem fordult elő

192

Nem tudom
$32 \%$

$77,3 \%$

4, $0 \%$

$3,3 \%$

$0,7 \%$

$6,3 \%$

$4,8 \%$

$28,2 \%$

$23,2 \%$

$31,2 \%$

$16,8 \%$

$0,7 \%$

$0,2 \%$

$1,3 \%$

$2 \%$

$41,3 \%$

$26,7 \%$ 
2. táblázat |A résztvevők csontritkulás-specifikus magatartásának és a belső konzisztencia vizsgálatának eredményei

\begin{tabular}{|c|c|c|c|c|c|c|}
\hline \multirow[t]{2}{*}{ Kategória } & \multirow[t]{2}{*}{ Átlag } & \multirow[t]{2}{*}{ Szórás } & \multirow[t]{2}{*}{ Medián } & \multicolumn{2}{|c|}{ Interkvartilis ráta } & \multirow[t]{2}{*}{ Cronbach-alfa } \\
\hline & & & & Alsó & Felső & \\
\hline OHBS - Hajlam a kórkép kialakulására & 15,47 & 5,94 & 15,00 & 12,00 & 19,00 & 0,921 \\
\hline OHBS - A kórkép súlyossága & 16,16 & 5,66 & 16,00 & 12,00 & 21,00 & 0,866 \\
\hline OHBS - A testmozgás előnyei & 22,60 & 4,06 & 23,00 & 20,00 & 25,00 & 0,908 \\
\hline OHBS - A kalciumbevitel elónyei & 24,35 & 5,12 & 24,00 & 22,00 & 29,00 & 0,849 \\
\hline OHBS - A testmozgás korlátai & 13,58 & 5,43 & 13,00 & 9,00 & 18,00 & 0,857 \\
\hline OHBS - A kalciumbevitel korlátai & 11,65 & 4,06 & 12,00 & 8,00 & 14,00 & 0,842 \\
\hline OHBS - Egészségügyi motiváció & 22,47 & 4,67 & 23,00 & 20,00 & 26,00 & 0,856 \\
\hline OHBS összes & 126,28 & 14,85 & 127,00 & 117,00 & 135,00 & 0,802 \\
\hline
\end{tabular}

OHBS $=($ Osteoporosis Health Belief Scale $)$ a csontritkulás-specifikus magatartás és attitúd vizsgálatára alkalmas kérdőiv

3. táblázat |Az OHBS teszt-reteszt és faktorelemzés eredményei

\begin{tabular}{|c|c|c|c|c|c|}
\hline Kérdés & $\begin{array}{l}\text { Teszt- } \\
\text { reteszt }\end{array}$ & $\begin{array}{l}\text { Faktor- } \\
\text { súly }\end{array}$ & Kérdés & $\begin{array}{l}\text { Teszt- } \\
\text { reteszt }\end{array}$ & $\begin{array}{l}\text { Faktor- } \\
\text { súly }\end{array}$ \\
\hline $\begin{array}{l}\text { 1. Az Ön esetében magas a csontritkulás kialakulásának } \\
\text { esélye. }\end{array}$ & 0,984 & 0,879 & $\begin{array}{l}\text { 22. Nem kell annyit aggódnia a csontritkulás miatt, } \\
\text { ha megfeleló a kalciumbevitele. }\end{array}$ & 0,988 & 0,734 \\
\hline $\begin{array}{l}\text { 2. Testfelépítése miatt Önnél nagyobb valószínúséggel } \\
\text { alakul ki a csontritkulás. }\end{array}$ & 0,987 & 0,690 & $\begin{array}{l}\text { 23. A megfeleló kalciumbevitel csökkenti a csonttörés } \\
\text { esélyét. }\end{array}$ & 0,983 & 0,772 \\
\hline 3. Nagy a valószínúsége, hogy csontritkulása lesz. & 1,000 & 0,919 & $\begin{array}{l}\text { 24. Elégedett magával, ha a megelőzés érdekében } \\
\text { gondoskodik a megfelelő kalciumbevitelrôl. }\end{array}$ & 0,982 & 0,722 \\
\hline 4. Jó esélye van, hogy csontritkulása legyen. & 0,992 & 0,898 & $\begin{array}{l}\text { 25. Úgy érzi, nem elég kitartó a rendszeres } \\
\text { testmozgáshoz. }\end{array}$ & 0,994 & 0,796 \\
\hline $\begin{array}{l}\text { 5. Nagyobb valószínúséggel lesz csontritkulása, mint egy } \\
\text { átlagembernek. }\end{array}$ & 1,000 & 0,844 & 26. Nincs megfelelő hely a testmozgáshoz. & 0,983 & 0,676 \\
\hline $\begin{array}{l}\text { 6. A családi kórtörténete miatt nagy esélye van a } \\
\text { csontritkulásra. }\end{array}$ & 0,983 & 0,764 & 27. Házastársa vagy családja elriasztja a testmozgástól. & 0,962 & 0,426 \\
\hline $\begin{array}{l}\text { 7. A gondolat, hogy csontritkulásban szenved, } \\
\text { megijeszti. }\end{array}$ & 0,980 & 0,671 & $\begin{array}{l}\text { 28. A rendszeres testmozgás beiktatása egy új } \\
\text { életmód kezdetét jelentené, amit nehéznek talál. }\end{array}$ & 1,000 & 0,823 \\
\hline 8. Ha csontritkulása lenne, rokkantnak érezné magát. & 0,983 & 0,797 & 29. A rendszeres testmozgás kényelmetlenül érinti. & 0,991 & 0,728 \\
\hline 9. Önértékelése megváltozna, ha csontritkulása lenne. & 0,992 & 0,842 & 30. A rendszeres testmozgás felborítja napi rutinját. & 0,981 & 0,746 \\
\hline 10. Anyagilag megterheló lenne, ha csontritkulása lenne. & 0,991 & 0,711 & 31. A kalciumban gazdag ételek túl drágák. & 0,934 & 0,621 \\
\hline 11. Lehangoltsággal tölti el, ha a csontritkulásra gondol. & 0,971 & 0,830 & $\begin{array}{l}\text { 32. A kalciumban gazdag ételek fogyasztása nem tesz } \\
\text { jót. }\end{array}$ & 0,972 & 0,729 \\
\hline 12. Komoly gond lenne, ha csontritkulásban szenvedne. & 0,984 & 0,738 & 33. Nem szereti a kalciumban gazdag ételeket. & 0,964 & 0,761 \\
\hline $\begin{array}{l}\text { 13. A rendszeres testmozgás segít a csontritkulásból } \\
\text { fakadó problémák megelôzésében. }\end{array}$ & 1,000 & 0,804 & $\begin{array}{l}\text { 34. A kalciumban gazdag ételek fogyasztása egy új } \\
\text { étrend bevezetését jelentené, amit nehéznek talál. }\end{array}$ & 0,979 & 0,751 \\
\hline $\begin{array}{l}\text { 14. Jó érzéssel tölti el, ha testmozgást végez, hogy } \\
\text { megelózze a csontritkulást. }\end{array}$ & 0,990 & 0,767 & $\begin{array}{l}\text { 35. A kalciumban gazdag ételek fogyasztása } \\
\text { érdekében fel kell hagynia más, kedvelt ételek } \\
\text { fogyasztásával. }\end{array}$ & 0,991 & 0,704 \\
\hline $\begin{array}{l}\text { 15. A rendszeres testmozgás segít az erős csontok } \\
\text { kialakításában. }\end{array}$ & 0,984 & 0,883 & $\begin{array}{l}\text { 36. A kalciumban gazdag ételeknek túl magas a } \\
\text { koleszterintartalmuk. }\end{array}$ & 0,945 & 0,660 \\
\hline $\begin{array}{l}\text { 16. A csontritkulás megelózése érdekében végzett } \\
\text { testmozgás javít teste kinézetén is. }\end{array}$ & 0,962 & 0,822 & 37. Étrendje kiegyensúlyozott. & 1,000 & 0,548 \\
\hline $\begin{array}{l}\text { 17. A rendszeres testmozgás csökkenti a csonttörés } \\
\text { esélyét. }\end{array}$ & 0,987 & 0,772 & $\begin{array}{l}\text { 38. Mindig keresi az egészséggel kapcsolatos új } \\
\text { információkat. }\end{array}$ & 0,985 & 0,757 \\
\hline $\begin{array}{l}\text { 18. Elégedett magával, ha a megelőzés érdekében } \\
\text { testmozgást végez. }\end{array}$ & 0,970 & 0,733 & $\begin{array}{l}\text { 39. Nagyon fontos az Ön számára, hogy egészséges } \\
\text { maradjon. }\end{array}$ & 0,983 & 0,753 \\
\hline $\begin{array}{l}\text { 19. A megfelelő kalciumbevitel megelózi a csontritkulás- } \\
\text { ból fakadó problémákat. }\end{array}$ & 0,983 & 0,773 & $\begin{array}{l}\text { 40. Próbálja minél korábban felismerni saját egészségi } \\
\text { problémáit. }\end{array}$ & 0,976 & 0,816 \\
\hline $\begin{array}{l}\text { 20. Sok előnye származik abból, ha a csontritkulás } \\
\text { megelőzése érdekében gondoskodik a megfelelő } \\
\text { kalciumbevitelrôl. }\end{array}$ & 0,921 & 0,681 & $\begin{array}{l}\text { 41. Akkor is rendszeresen ellenőrzi egészségi } \\
\text { állapotát, ha nem beteg. }\end{array}$ & 0,976 & 0,761 \\
\hline $\begin{array}{l}\text { 21. A megfelelő kalciumbevitel segít megelőzni a } \\
\text { fájdalmas csontritkulást. }\end{array}$ & 0,955 & 0,778 & $\begin{array}{l}\text { 42. Betartja az ajánlásokat, hogy egészséges } \\
\text { maradjon. }\end{array}$ & 0,968 & 0,799 \\
\hline
\end{tabular}

OHBS $=($ Osteoporosis Health Belief Scale $)$ a csontritkulás-specifikus magatartás és attitűd vizsgálatára alkalmas kérdő́iv 
alacsony (2. táblázat). Az OKAT tekintetében a válaszadók a megszerezhető 20 pontból mindössze $8,78 \pm 3,1$ pontot értek el.

A faktorelemzés alkalmas arra, hogy megvizsgáljuk, egy új nyelvre lefordított kérdő́iv alkalmas-e az adott nyelven ugyanazt mérni, amit az eredeti kérdő́ív mér. A 42 kérdéses kérdőívet bevontuk az elemzésbe, és a faktorelemzés 7 faktort különített el, melyek megfeleltethetők az eredeti faktoroknak. A KMO-teszt 0,6 felett tekinthetó elfogadhatónak; esetünkben a KMO-teszt $(\mathrm{KMO}=0,886)$ és a Bartlett-próba $(\mathrm{p}<0,001)$ igazolta, hogy az adatok alkalmasak a feltáró faktoranalízisre: a 7 faktor a vizsgált tényezők 63\%-át magyarázta, tehát a teszt egyes kérdéseiből származó információk 37\%-át veszítjük el a faktorokba, alskálákba rendezés során, ami megfelel a kritériumoknak (3. táblázat).

\section{A kérdőin megbizhatóságának vizsgálata}

A Cronbach-alfa-értékkel a kérdőív belső konzisztenciáját, megbízhatóságát vizsgáltuk. A Cronbach-alfa elfogadható, amennyiben 0,7-0,85 értéket vesz fel. Az OHBS esetén a dimenziók értéke több esetben is meghaladja a 0,85 értéket, de a teljes kérdőívre kivetített Cronbach-alfa-érték $(0,802)$ a kielégító tartományba sorolandó (2. táblázat).

A kérdőív megbízhatóságát teszt-reteszt vizsgálattal is alátámasztottuk, melyhez Spearman-féle korrelációskoefficiens-elemzést alkalmaztunk (3. táblázat). 0,8 felett megbízhatónak tekinthető az adott kérdés - kérdő́ivünk esetén a korrelációs koefficiens értéke 0,921 és 1,000 közötti volt az egyes kérdéseknél.

\section{Az OHBS-kérdő̂́v konvergens validitásának vizsgálata}

Vizsgálatunk és számításaink alapján az életkor gyenge szorossági kapcsolatban áll a betegségspecifikus attitúddel. Az életkornál nagyobb mértékben határozza meg a beteg hozzáállását és magatartását a legmagasabb iskolai végzettsége. Kiemelendő kapcsolatot mutat a legmagasabb iskolai végzettség az "Egészségügyi motiváció” $(\mathrm{p}<0,001 ; \mathrm{R}=0,22)$, továbbá „A kalciumbevitel korlátai” $(\mathrm{p}<0,001 ; \mathrm{R}=-0,23)$ és „A testmozgás korlátai” $(\mathrm{p}<0,001 ; \mathrm{R}=-0,17)$ dimenziókkal. Az OKAT vizsgálata során szintén hasonló eredményre jutottunk: a betegségspecifikus tudás szorosabb kapcsolatban állt a legmagasabb iskolai végzettséggel $(\mathrm{p}=0,01 ; \mathrm{R}=0,11)$, mint az életkorral $(\mathrm{p}=0,326 ; \mathrm{R}=0,04)$. A betegségspecifikus tudás és az OHBS-dimenziók összevetésekor szignifikáns korrelációs kapcsolatot véltünk felfedezni „A testmozgás előnyei” ( $\mathrm{p}<0,001 ; \mathrm{R}=0,17)$, „A kalciumbevitel korlátai” $(\mathrm{p}<0,001 ; \mathrm{R}=-0,18)$, továbbá az „Egészségügyi motiváció" $(\mathrm{p}<0,001 ; \mathrm{R}=0,16)$ dimenziók vizsgálata során (4. táblázat).
4. táblázat $\mid$ Az OHBS-kérdőív konvergens validitási vizsgálatának eredményei

\begin{tabular}{|c|c|c|c|}
\hline & Életkor & Iskolai végzettség & OKAT összes \\
\hline \multirow[t]{2}{*}{ OHBS 1.} & $0,11^{* *}$ & $-0,06$ & 0,08 \\
\hline & 0,007 & 0,156 & 0,056 \\
\hline \multirow[t]{2}{*}{ OHBS 2.} & $-0,195^{* *}$ & $-0,11^{* *}$ & $-0,04$ \\
\hline & 0,000 & 0,006 & 0,333 \\
\hline \multirow[t]{2}{*}{ OHBS 3.} & $-0,03$ & 0,01 & 0,05 \\
\hline & 0,455 & 0,806 & 0,192 \\
\hline \multirow[t]{2}{*}{ OHBS 4.} & $0,08^{*}$ & $0,15^{* *}$ & $0,17^{* *}$ \\
\hline & 0,040 & 0,000 & 0,000 \\
\hline \multirow[t]{2}{*}{ OHBS 5.} & 0,05 & $-0,17^{* *}$ & $-0,07$ \\
\hline & 0,262 & 0,000 & 0,113 \\
\hline \multirow[t]{2}{*}{ OHBS 6.} & $0,1^{*}$ & $-0,23^{* *}$ & $-0,18^{* *}$ \\
\hline & 0,018 & 0,000 & 0,000 \\
\hline \multirow[t]{2}{*}{ OHBS 7.} & $0,19^{* *}$ & $0,22^{* *}$ & $0,16^{* *}$ \\
\hline & 0,000 & 0,000 & 0,000 \\
\hline \multirow[t]{2}{*}{ OHBS összes } & 0,07 & $0,19^{*}$ & 0,07 \\
\hline & 0,095 & 0,030 & 0,097 \\
\hline \multirow[t]{2}{*}{ OKAT összes } & 0,04 & $0,11^{* *}$ & 1,000 \\
\hline & 0,326 & 0,010 & - \\
\hline
\end{tabular}

*A korreláció szignifikanciaszintje $\mathrm{p}<0,05$

${ }^{* *}$ A korreláció szignifikanciaszintje $p<0,01$

OHBS 1. - Hajlam a kórkép kialakulására

OHBS 2. - A kórkép súlyossága

OHBS 3. - A kalciumbevitel előnyei

OHBS 4. - A testmozgás előnyei

OHBS 5. - A testmozgás korlátai

OHBS 6. - A kalciumbevitel korlátai

OHBS 7. - Egészségügyi motiváció

OHBS $=($ Osteoporosis Health Belief Scale $)$ a csontritkulás-specifikus magatartás és attitúd vizsgálatára alkalmas kérdőív; OKAT $=($ Osteoporosis Knowledge Assessment Tool) a csontritkulás-specifikus tudásszintet értékelő index

\section{Megbeszélés}

A vizsgálat célja volt az első, osteoporosisspecifikus magatartást és attitû́döt vizsgáló OHBS-kérdőív validációja, mely a továbbiakban segíthet a magyar anyanyelvú női populáció osteoporosisspecifikus attitúdjének vizsgálatában, továbbá alkalmazásával a betegedukációs programok monitorozhatóvá válnak.

Keresztmetszeti vizsgálatunkban és a validáció folyamatában a nemzetközi mintát és az eredeti kérdő́iv első szerzőjének tanácsait követtük, így az OHBS mellett egy csontritkulás-specifikus tudást vizsgáló kérdőívet (OKAT) és saját szerkesztésü kérdőívet alkalmaztunk $[13,17]$.

Mintánkban közel azonos számban voltak jelen 40 év alatti $(n=323)$ és 40 év feletti $(n=277)$ nők, akik a lakhelyük típusát, családi állapotukat, iskolai végzettségüket tekintve széles megoszlást mutatnak, így teljes 
körü képet adnak a magyarországi viszonyokról a csontritkulással kapcsolatos tudás és attitúd tekintetében.

Az OHBS teljes kérdőív eredményei $(126,28 \pm 14,85$ pont) és a 7 dimenzió részeredményei („Hajlam a kórkép kialakulására” - 15,47 $\pm 5,94$ pont; „A kórkép súlyossága” - 16,16 $\pm 5,66$; „A testmozgás előnyei” - 22,6 \pm 4,06 pont; „A kalciumbevitel előnyei” - 24,35 $\pm 5,12$ pont; „A testmozgás korlátai” - 13,58 $\pm 5,43$ pont; "A kalciumbevitel korlátai” - 11,65 \pm 4,06 pont; „Egészségügyi motiváció” - 22,47 \pm 4,67 pont) egyaránt a nemzetközi kutatások eredményeihez hasonló értéket mutatnak [24-26].

A 42 kérdéses kérdőív magyar verziója ugyanazon 7 alskálára bontható a kérdések tárgyát tekintve, mint az eredeti OHBS-kérdőív, az alkalmazott feltáró faktorelemzés eredményei alapján. Mindez alátámasztja azt is, hogy a méróeszköz elemeinek magyar nyelvú adaptációja sikeres volt.

Az OKAT eredményei esetén mintánk átlaga 8,78 \pm 3,1 pont volt a megszerezhető 20 pontból, ami akár a nemzetközi szakirodalom eredményeivel, akár a magyarországi korosztálynak megfelelő átlaggal (11,33 \pm 4,33 pont) összehasonlítva alacsony tudásszintet mutat [13].

A nemzetközi szakirodalomban a betegségspecifikus kérdőívek esetén számos alkalommal hasonlították össze az egészségügyi és a nem egészségügyi dolgozók eredményeit $[10,13,17,18]$. Mivel a jelen kutatásban a kitöltők mindössze 15,2\%-a rendelkezett egészségügyi végzettséggel, az összehasonlító vizsgálat nem hozna releváns eredményt.

A nemzetközi szakirodalom alapján a betegségspecifikus tudás és attitűd kialakulásában fontos szerepet tölt be a legmagasabb iskolai végzettség [10, 18-20]. Vizsgálatunk ezt alátámasztotta, hiszen az mind az OKAT $(\mathrm{R}=0,11 ; \mathrm{p}=0,01)$, mind az OHBS $(\mathrm{R}=0,19 ; \mathrm{p}=$ 0,03 ) eredményeivel szignifikáns korrelációs kapcsolatot mutatott.

A belső konzisztencia vizsgálatára alkalmazott Cronbach-alfa a magyar OHBS-dimenziókat illetően több dimenzió esetén is magasabb értéket vesz fel, mint az optimális $(0,7-0,85)$, hasonlóan a maláj és az arab verzióhoz, ezért megbízhatónak tartjuk a kérdőívet, továbbá a teljes kérdőívre nézve az érték 0,802, amely az elfogadhatósági tartományba esik [24, 27]. Az eredeti kérdőív validációs értékeihez hasonlóan a legmagasabb Cronbach-alfa-értéket a „Hajlam a kórkép kialakulására” és „A testmozgás elónyei” dimenziók mutatják [14]. A teszt-reteszt vizsgálat során a korrelációs koefficiens 0,921 és 1,000 közötti értéket mutatott.

Eredményeinknek a nemzetközi szakirodalom eredményeivel való összehasonlítása alapján az OHBS magyar adaptációját érvényes és megbízható kérdőívnek tartjuk a magyar anyanyelvú női populáció osteoporosisspecifikus attitűdjének vizsgálatára.
Anyagi támogatás: A közlemény megírása, illetve a kapcsolódó kutatómunka anyagi támogatásban nem részesült.

Szerzői munkamegosztás: T. P., K. I.: A kapott adatok feldolgozása, szakirodalmi kutatás, végköveztetések. M. A.: A kutatás statisztikai számításainak elvégzése, helyességük ellenőrzése. Sz. B.: A kérdőív fordításának szakmai ellenőrzése. K. I.: A vizsgálati alanyok gyưjtése, a kérdőívek kitöltetése. H. M.: A vizsgálati helyszín biztosítása, a vizsgálati engedély megadása. J. M.: A vizsgálati alanyok gyüjtése, a kérdőívek kitöltetése, kutatásmódszertani és szakmai ellenőrzés. A cikk végleges változatát valamennyi szerző elolvasta és jóváhagyta.

Érdekeltségek: A szerzőknek nincsenek érdekeltségeik.

\section{Irodalom}

[1] Kanis JA, Cooper C, Rizzoli R, et al. European guidance for the diagnosis and management of osteoporosis in postmenopausal women. Osteoporos Int. 2019; 30: 3-44. [Erratum: Osteoporos Int. 2020; 31: 209.] [Erratum: Osteoporos Int. 2020; 31: 801.]

[2] Ciubean AD, Ungur RA, Irsay L, et al. Health-related quality of life in Romanian postmenopausal women with osteoporosis and fragility fractures. Clin Interv Aging 2018; 13: 2465-2472.

[3] Miyakoshi N, Kudo D, Hongo M, et al. Comparison of spinal alignment, muscular strength, and quality of life between women with postmenopausal osteoporosis and healthy volunteers. Osteoporos Int. 2017; 28: 3153-3160.

[4] Borgström F, Karlsson L, Ortsäter G, et al. Fragility fractures in Europe: burden, management and opportunities. Arch Osteoporos. $2020 ; 15: 59$.

[5] Pisani P, Renna MD, Conversano F, et al. Major osteoporotic fragility fractures: risk factor updates and societal impact. World J Orthop. 2016; 7: 171-181.

[6] Hungarian Central Statistical Office. We can do for our health. European Health Interview Survey - 2019. [Tehetünk az egészségünkért. Európai Lakossági Egészségfelmérés 2019.] Központi Statisztikai Hivatal, Budapest, 2019. Available from: https:// www.ksh.hu/docs/hun/xftp/idoszaki/elef/te_2019/index. html\#krnikusbetegeks [accessed: February 20, 2021]. [Hungarian]

[7] International Osteoporosis Foundation. Key statistics for Europe. Available from: https://www.osteoporosis.foundation/ facts-statistics/key-statistic-for-europe [accessed: February 20, $2021]$.

[8] Darout IA, Alamir A, Sultana S. Osteoporosis knowledge and related health behavior among women in Jazan Region, Kingdom of Saudi Arabia. J Contemp Dent Pract. 2017; 18: 378382.

[9] Miller TA. Health literacy and adherence to medical treatment in chronic and acute illness: a meta-analysis. Patient Educ Couns. 2016; 99: 1079-1086.

[10] Kovács-Babócsay B, Makai A, Szilágyi B, et al. The Hungarian translation and validation of the Low Back Pain Knowledge Questionnaire. [Egy deréktáji fájdalommal kapcsolatos betegségspecifikus tudást felmérő külföldi kérdőív hazai, magyar nyelvű validálása.] Orv Hetil. 2019; 160: 1663-1672. [Hungarian]

[11] Szathmári M. Evaluation of fracture risk in osteoporosis. [A csonttörés kockázatának megítélése osteoporosisban.] Orv Hetil. 2011; 152: 1304-1311. [Hungarian] 
[12] Vokó Z, Inotai A, Horváth Cs, et al. Quality of life of patients with osteoporosis in Hungary. [Csontritkulásban szenvedő betegek életminősége Magyarországon.] LAM KID 2013; 3: $35-41$.

[13] Tardi P, Szilágyi B, Makai A, et al. The development of a reliable and valid instrument to measure the osteoporosis-related knowledge: validation of the Hungarian version of Osteoporosis Knowledge Assessment Tool (OKAT). BMC Public Health 2021; 21(Suppl 1): 1515 .

[14] Kim KK, Horan ML, Gendler P, et al. Development and evaluation of the Osteoporosis Health Belief Scale. Res Nurs Health 1991; 14: 155-163.

[15] McLeod KM, Johnson CS. A systematic review of osteoporosis health beliefs in adult men and women. J Osteoporos. 2011; 2011: 197454 .

[16] Beaton DE, Bombardier C, Guillemin F, et al. Guidelines for the process of cross-cultural adaptation of self-report measures. Spine 2000; 25: 3186-3191.

[17] Sayed-Hassan RM, Bashour HN. The reliability of the Arabic version of osteoporosis knowledge assessment tool (OKAT) and the osteoporosis health belief scale (OHBS). BMC Res Notes 2013; 6: 138.

[18] Sayed-Hassan R, Bashour H, Koudsi A. Osteoporosis knowledge and attitudes: a cross-sectional study among female nursing school students in Damascus. Arch Osteoporos. 2013; 8: 149.

[19] Bilal M, Haseeb A, Merchant AZ, et al. Knowledge, beliefs and practices regarding osteoporosis among female medical school entrants in Pakistan. Asia Pac Fam Med. 2017; 16: 6.

[20] Senthilraja M, Cherian KE, Jebasingh FK, et al. Osteoporosis knowledge and beliefs among postmenopausal women: a crosssectional study from a teaching hospital in southern India. J Family Med Prim Care 2019; 8: 1374-1378.
[21] MacCallum RC, Widaman KF, Zhang S, et al. Sample size in fac tor analysis. Psychol Methods 1999; 4: 84-99.

[22] Ács P. (ed.) Methodology of sports science research. [Sporttudományi kutatások módszertana.] Pécsi Tudományegyetem, Egészségtudományi Kar, Pécs, 2015. Available from: https:// www.etk.pte.hu/protected/OktatasiAnyagok/\%21Palyazati/ sport2/SporttudomanyiKutatasokModszertana_1028_elektronikus_k.pdf [accessed: February 20, 2021].

[23] Cronbach LJ. Coefficient alpha and the internal structure of tests. Psychometrika 1951; 16: 297-334. https://doi. org/10.1007/BF02310555

[24] Sahib MN. Psychometric properties and assessment of the Osteoporosis Health Belief Scale among the general Arabic population. Patient Prefer Adherence 2018; 12: 223-232.

[25] Dai W, Peng L, Xiong Y, et al. Osteoporosis health beliefs and self-efficacy among orthopedic nurses in Hunan Province, China. Int J Orthop Trauma Nurs. 2020; 40: 100839.

[26] Gopinathan NR, Sen RK, Behera P, et al. Awareness of osteoporosis in postmenopausal Indian women: an evaluation of Osteoporosis Health Belief Scale. J Midlife Health 2016; 7: 180-184.

[27] Abdulameer SA, Syed Sulaiman SA, Hassali MA, et al. Psychometric properties of the Malay version of the Osteoporosis Health Belief Scale (OHBS-M) among type 2 diabetic patients. Int J Rheum Dis. 2014; 17: 93-105.

(Tardi Péter, Pécs, Vörösmarty u. 3., 7621 e-mail: peter.tardi@etk.pte.hu)

\section{"Utilibus monitis prudens accomodet aurem." (Meghallgatja, ki bölcs, ha javát szolgálja, az intést.)}

A cikk a Creative Commons Attribution 4.0 International License (https://creativecommons.org/licenses/by/4.0/) feltételei szerint publikált Open Access közlemény, melynek szellemében a cikk bármilyen médiumban szabadon felhasználható, megosztható és újraközölhető, feltéve, hogy az eredeti szerző és a közlés helye, illetve a CC License linkje és az esetlegesen végrehajtott módositások feltüntetésre kerülnek. (SID_1) 